(C) М.М. Толстушко, к.т.н., С.Ф. Юхимчук, к.т.н., Н.О. Толстушко, к.т.н., А.В. Силивонюк, к.т.н. Луцький національний технічний університет

\title{
ДИНАМОМЕТРУВАННЯ ВИВІДНОГО ПРИСТРОЮ ЛЬОНОЗБИРАЛЬНОЇ МАШИНИ
}

У статті наведено методику та результати динамометрування вивідного пристрою льонозбиральної машини. Визначено тягове зусилля приводу вивідного пристрою льонозбиральної машини. 
ЛЬОНОЗБИРАЛЬНА МАШИНА, ВИВІДНИЙ ПРИСТРІЙ, ВІЗОК, ПРИВОД, ТЯГОВЕ ДИНАМОМЕТРУВАННЯ, СТРІЧКА ЛЬОНУ

ЗУСИЛЛЯ,

Постановка проблеми. Наявні вивідні пристрої льонозбиральних машин повинні забезпечувати якісне розстилання стеблової стрічки льону на льоновищі. Робота цих пристроїв льонозбиральних машин у значній мірі впливає на важливі характеристики стеблових стрічок льону. Отже, актуальним завданням є забезпечення високої якості розстилання стеблової стрічки льонозбиральними машинами [1-4].

Аналіз останніх досліджень і публікацій свідчить про те, що $\epsilon$ велика кількість наукових робіт присвячених вивідним пристроям льонозбиральних машин [1-4]. Значний обсяг робіт в цьому напрямку проведено професором Г.А. Хайлісом та учнями його наукової школи. Дослідження роботи вивідних пристроїв льонозбиральних машин продовжується [1-4].

Мета дослідження - визначити у лабораторних умовах тягове зусилля приводу вивідного пристрою 3 активною робочою поверхнею льонозбиральної машини.

Результати дослідження. Лабораторна установка для динамометрування вивідного пристрою 3 активною робочою поверхнею льонозбиральної машини (рис. 1) була встановлена на основі тягового візка 1, грунтового каналу 2 і виготовленого раніше вивідного пристрою 3 для льонозбиральної машини [2, 3]. На краю тягового візка була закріплена рамка, до якої під кутом до горизонту були приварені паралельні прутки 4 та вуха для кріплення вивідного пристрою. Тяговий візок 1 переміщувався на рейках грунтового каналу 2 за допомогою закріпленого до візка троса 5, який намотувався на лебідку. Опорно-приводне колесо вивідного пристрою опиралось на втрамбований до певної твердості грунт каналу $[2,3]$.

Для динамометрування вивідного пристрою був спеціально виготовлений динамограф 6, який з'єднувався 3 тросом 5. Для визначення тягового зусилля приводу вивідного пристрою льонозбиральної машини на основі динамометра ДПУ-0,2-2 виготовлений динамограф, зображений на рис. $2[2,3]$. 


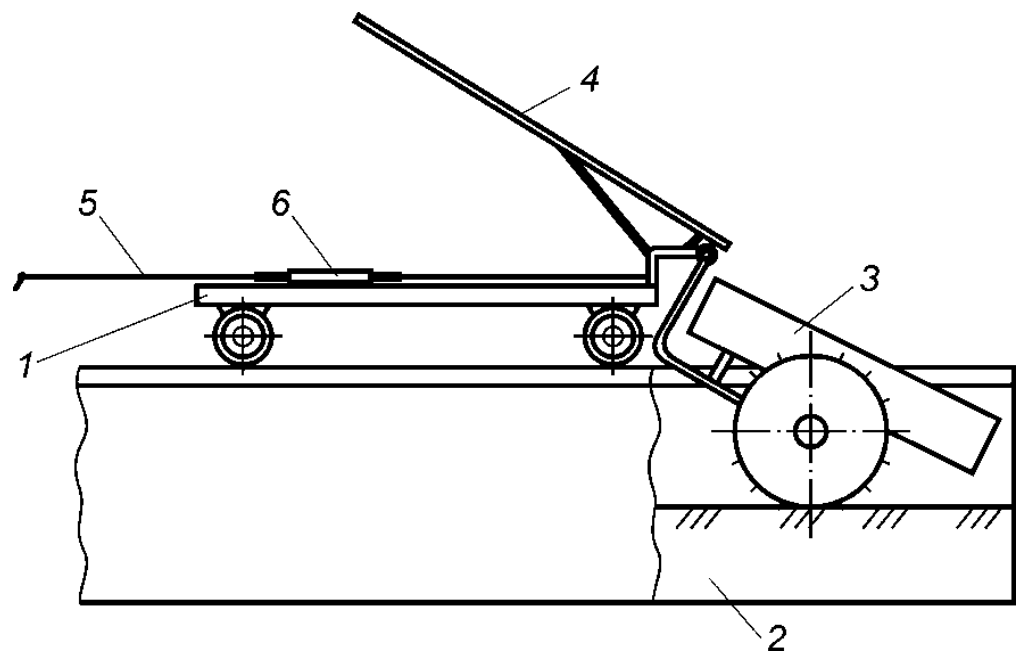

Рис. 1 - Схема установки для динамометрування вивідного пристрою льонозбиральної машини у лабораторних умовах: 1 - тяговий візок; 2 - грунтовий канал; 3 - вивідний пристрій; 4 - прутки; 5 - трос; 6 - динамограф.

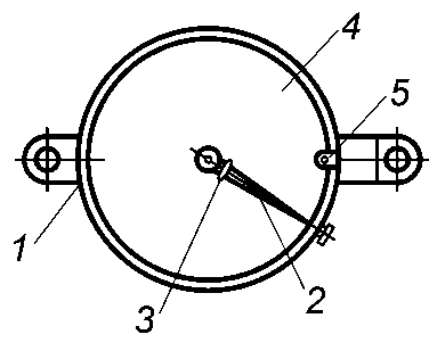

Рис. 2 - Схема динамографа: 1 - динамометр; 2 - конусний стрижень; 3 - кільце; 4 - білий цупкий папір; 5 - затискач.

У даному динамометрі ДПУ-0,2-2 була демонтована заводська стрілка. На циферблат динамометра 1 накладалась i фіксувалась копірка та білий цупкий папір таким чином, щоб фарбувальна сторона копірки торкалась паперу. Замість стрілки на вісь динамометра 1 встановлювався конусний стрижень 2 , на який надівалось кільце 3 , яке могло обертатись на стрижні і торкатись паперу 4, закріпленого на циферблаті затискачем 5. Під час 
коливання конусного стрижня кільце поступово переміщувалось вздовж його осі.

Спочатку проводили динамометрування тягового візка (рис. 3). Для цього на прутки вкладали стеблову стрічку льону, до гака тягового візка і кінця троса кріпили динамограф, кільце якого розміщувалось біля його осі. За допомогою лебідки переміщували тяговий візок вздовж грунтового каналу. У кінці каналу візок зупиняли, знімали динамограф і виймали 3 нього верхній папір, попередньо відмітивши на ньому нульовий рівень шкали динамометра. На папері, за рахунок притискання його кільцем до кальки, викреслювалась траєкторія руху кільця завдяки коливанням стрижня. Відмічали дві крайні точки на отриманій траєкторії. Визначали радіуси положення цих точок. Від більшого радіуса віднімали менший і отриману відстань ділили на три ділянки. Розглядали зону, що відповідає товщині середньої ділянки. При цьому через центр паперового диска проводили пряму, яка проходить через точки даної зони, що відповідають найчастішому положенню стрижня. Визначали кут між даною прямою і рискою, що відповідає нульовому рівню, відкладали цей кут від нульового рівня циферблата динамометра i отримували характерне тягове зусилля на привод візка. Брали чистий паперовий диск та проробляли аналогічно наступні досліди [2, 3].

Тягове зусилля приводу вивідного пристрою визначали для двох випадків, коли палець його коромисла розміщувався біля центру обертання опорно-приводного колеса i коли - на його периферії. Тут покази динамографа знімались аналогічно як і для визначення тягового зусилля приводу візка.

Досліди проводились у триразовій повторюваності. Отримані значення тягових зусиль фіксувались у зошиті i оброблялись. Після чого, віднімаючи від тягового зусилля приводу візка з вивідним пристроєм тягове зусилля приводу тільки візка, визначали тягове зусилля приводу вивідного пристрою.

Грунт у каналі зволожувався до вологості 20..22\% i ущільнювався до твердості $80 \ldots 90 \mathrm{H} / \mathrm{cm}^{2}$. Для дослідів бралась стеблова стрічка таких характеристик: довжина стебел - 74...83 см, вологість - 52 \%, стебла обчісані, товщина стрічки - 6...9 мм.

Тягове зусилля на привод вивідного пристрою визначали на середній швидкості руху візка - 2 м/с [2, 3]. 


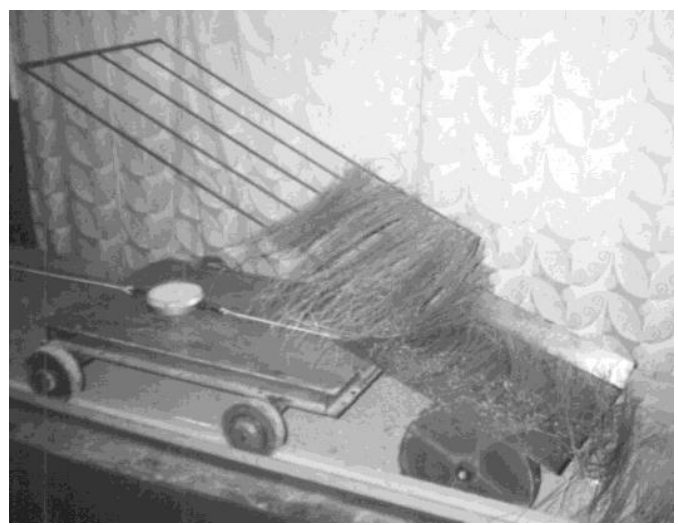

Рис. 3 - Визначення тягового зусилля приводу вивідного пристрою у лабораторних умовах

Висновки. Після аналізу одержаних результатів, виключення тягового зусилля на переміщення візка, встановлено, що тягове зусилля приводу вивідного пристрою під час роботи вхолосту становить для випадку, коли палець коромисла розміщувався біля центра обертання опорно-приводного колеса $84,3 \mathrm{H}$, а коли на периферії колеса $-87,8$ Н. Коли ж вивідний пристрій виконує розстилання 3 одночасним підрівнюванням стеблової стрічки, то тягове зусилля приводу вивідного пристрою у першому випадку склало 109,2 Н, а в другому - 117,4 Н [2, 3].

\section{Література}

1. Хайлис Г.А. Теория льноуборочных машин / Хайлис Г.А. М.: Росинформагротех, 2011. - 322 с.

2. Толстушко М.М. Обгрунтування параметрів і режиму роботи підрівнювача-розстилача стрічки стебел льону: дис. ... канд. техн. наук: 05.05.11 / Толстушко Микола Миколайович. - Луцьк, 2004. $229 \mathrm{c}$.

3. Толстушко М.М. Розстилальні пристрої льонозбиральних машин / Толстушко М.М., Хайліс Г.А., Толстушко Н.О. - Луцьк: Ред.-вид. відділ ЛНТУ, 2014. - 160 с.

4. Толстушко Н.О. Рулонні прес-підбирачі / Толстушко Н.О., Хайліс Г.А., Толстушко М.М. - Луцьк: ІВВ Луцького НТУ, 2018. $164 \mathrm{c.}$ 